logos_i_ethos_2021_2_(58), s. 147-167

https://doi.org/10.15633/lie.4174

Krzysztof Kotula

https://orcid.org/0000-0002-2698-9692

Uniwersytet Papieski Jana Pawła II w Krakowie

\title{
Sporne zagadnienia antropologiczne i historiozoficzne w rozważaniach Jacques'a Maritaina
}

Powszechnie ceniony w Polsce na katolickich uniwersytetach Jacques Maritain był odpowiedzialny za odnowienie studiów tomistycz-

Krzysztof Kotula, absolwent filozofii i teologii na Uniwersytecie Papieskim Jana Pawła II w Krakowie, doktorant z filozofii w Szkole Doktorskiej UPJPII. nych, do czego wezwał za swojego pontyfikatu papież Leon XIII. Maritain uważał tomizm za nurt progresywny i asymilujący, był otwarty na ustalenia nauk przyrodniczych (studiował również biologię) i chciał ująć człowieka oraz problemy, przed jakimi on staje, w możliwie najszerszy sposób, bez żadnego upraszczania i redukowania jakiegokolwiek aspektu rzeczywistości do innego, rzekomo bardziej pierwotnego. Niektóre rozstrzygnięcia Maritainowskiego personalizmu zdają się odbiegać od bardziej klasycznych ujęć tomizmu i spotkały się one $\mathrm{z}$ mniej lub bardziej natężoną krytyką. Te sporne zagadnienia $\mathrm{z}$ filozofii francuskiego myśliciela oraz stanowiska wobec nich krytyczne są przedmiotem niniejszego artykułu.

\section{Ogólny przegląd spornych zagadnień i wstępne uwagi o krytyce}

Wydaje się, że szczątkową próbę zrekonstruowania stanowisk krytycznych wobec filozofii Maritaina warto rozpocząć od przynajmniej bardzo ogólnej klasyfikacji domniemanych bądź faktycznych błędów francuskiego neotomisty. Otóż, można powiedzieć, że z jednej strony oponenci 
wytykali mu błędy bardziej praktyczne, dotyczące jego sposobu wyrażania się czy też nazewnictwa, jakie stosował; a także bardziej teoretyczne, które łączą się chociażby z takimi problemami jak: nieadekwatność Maritainowskiego rozróżnienia na osobę i jednostkę, konglomerat twierdzeń wiążących się mniej lub bardziej z historyzmem i progresywizmem, wreszcie amerykanizm.

Z drugiej strony czymś godnym uwzględnienia jest fakt, że jeden z pierwszych polemistów Humanizmu integralnego, pozostającego sztandarowym dziełem Maritaina, Louis Salleron zauważył, że nie jest łatwo krytykować Maritaina, ponieważ rozpościera się wokół niego aura uczoności, a nawet świętości. Sprzeciwiający się mu ludzie nie mogą pozbyć się dyskomfortu i niepokoju spowodowanych obawą, że myśl uczonego, tak głęboko zakorzeniona w filozofii św. Tomasza z Akwinu, przerasta ich pojmowanie rzeczy i tak naprawdę jest czystą ortodoksją, która pozostaje tak skomplikowana, że znacząco wykracza poza ich znajomość doktryny katolickiej i realistycznej filozofii ${ }^{1}$. Jak widać, nawet adwersarze Maritaina chylili czoła przed jego dorobkiem naukowym i wskazywali na głębokie zakorzenienie tego autora w myśli św. Tomasza z Akwinu. Z tego powodu uzasadnione będzie poświęcenie uwagi szczególnie zagadnieniu Maritainowskiego rozróżnienia na osobę i jednostkę, co jest tematem typowo tomistycznym. Jednak zanim zostanie podjęty ten wątek, należy, pozostając w zgodzie z już przedstawioną klasyfikacją, przeanalizować problem terminologii stosowanej przez Maritaina.

\section{Terminologiczny problem humanizmu integralnego}

Poprzez humanizm integralny rozumiemy całościowy program społeczno-polityczny Maritaina. Program ten miał wydobyć człowieka z opresji $\mathrm{z}$ jednej strony marksizmu, $\mathrm{z}$ drugiej liberalizmu. Zrealizowany, miał doprowadzić do powstania nowej cywilizacji chrześcijańskiej, w której żaden $\mathrm{z}$ aspektów ludzkiego jestestwa nie będzie deprecjonowany,

1 Por. M. Davies, Sobór papieża Jana: rewolucja liturgiczna, tłum. A. Zdziech, Komorów 2011, s. 338 . 
dzięki czemu człowiek będzie mógł rozwijać się w życiu doczesnym i swobodnie otwierać na transcendencję oraz życie wieczne.

Już wspomniany Salleron krytykował nazewnictwo stosowane przez filozofa jako dziwaczne i prowadzące czytelnika na manowce. Propagowany przez siebie humanizm Maritain nazwal integralnym - opartym na Bogu, a nie skoncentrowanym na człowieku. Zdaniem francuskiego neotomisty fatalną pomyłką humanizmu nie było to, że był humanizmem, lecz fakt, że pozostawał antropocentryczny. Salleron uznał ten pogląd za absurdalny, według niego, humanizm z definicji jest skoncentrowany na człowieku, na tym polega jego istota. Zestawienie słów „humanizm antropocentryczny” to jedynie pleonazm - użycie greckiej podstawy słowotwórczej, powtarzającej znaczenie rzeczownika pochodzącego z języka łacińskiego.

Humanizm narodził się w XVI wieku i był reakcją na teocentryzm średniowiecza; za każdym razem, gdy odżywa, za sprawą każdej nowej rewolucji, jest przeciwstawieniem człowieka $\mathrm{Bogu}^{2}$. Maritain w $\mathrm{Hu}$ manizmie integralnym deklarował, że wierzy, iż jego humanizm posiada moc ocalenia i przechowania wszystkiego tego, co jest prawdą w obrębie humanizmu socjalistycznego. Miałoby się to dokonać poprzez zjednoczenie tych prawd w organiczny i życiodajny sposób z wieloma innymi prawdami.

Salleron uważał, że pod względem czysto logicznym jest to niepodważalna prawda; niemniej jednak nie popierał nazywania tego zbioru prawd mianem integralnego humanizmu. Jego zdaniem równie dobrze można by nazwać taki program integralnym komunizmem - ze względu na fakt, że zło jest brakiem, każde „zintegralizowane” zło staje się dobre, w gruncie rzeczy staje się dobrem. Natomiast każdy błąd staje się prawdą, jeśli przetransportuje jakąkolwiek prawdę, którą ze sobą niesie, na plan absolutu. W tym kontekście Salleron stwierdził, że największy grzesznik, popełniający codziennie wszystkie grzechy główne, poszukuje jakiegoś dobra i ktoś mógłby mu powiedzieć, ażeby udał się do Boga, 
a otrzyma to, czego rzeczywiście pragnie (autentyczne dobro), jednak nie jest to powód, by świętość ogłosić „integralnym grzechem”.

\section{Rozróżnienie na osobę i jednostkę}

Polski marksistowski badacz myśli Maritaina - Tadeusz Mrówczyński zasygnalizował, że praktyczne, terminologiczne problemy są widoczne również w Maritainowskim rozróżnieniu na osobę i jednostkę, które nie jest do końca sprecyzowane i opiera się na mglistych metafizycznych intuicjach $^{4}$. Ta mglistość sprawia, że konsekwencje społeczne tego zabiegu jawią się jako nie do końca spójne. Rozróżnienie na osobę i jednostkę jest być może najistotniejszym punktem spornym w obrębie filozofii Maritaina. Żeby je solidnie omówić, należy cofnąć się do samego św. Tomasza $\mathrm{z}$ Akwinu oraz wyszczególnionych na bazie jego filozofii dwudziestu czterech tez tomistycznych, stanowiących streszczenie tomizmu.

Cała refleksja antropologiczna i polityczno-społeczna Maritaina jest osadzona na gruncie klasycznej filozofii realistycznej, odwołującej się do dziedzictwa Arystotelesa i św. Tomasza z Akwinu. Francuski myśliciel jako tomista, uznawał istnienie odrębnej od człowieka rzeczywistości, z którą kontakt stanowi początek ludzkiego poznania. Według realizmu to nie myśl ludzka konstruuje świat, lecz że istniejące realnie, poza ludzką świadomością, byty warunkują pojawienie się idei w ludzkim intelekcie. Bytów tych nie da się, wedle tomistów, sprowadzić do jakiegoś jednego czynnika (metafizyczny monizm). Realizm nie lekceważy w ludzkim poznaniu „słusznych praw” zdrowego rozsądku i stara się czynić poznanie możliwie jak najbardziej obiektywnym oraz uniwersalnym, poprzez staranie się o neutralność w punkcie wyjścia filozoficznych dociekań, dążenie do autonomii filozofii wobec innych nauk, a także odrzucanie skrajnych postaw filozoficznych (takich jak np. wspomniany monizm).

3 Por. M. Davies, Sobór papieża Jana, s. 339-340.

4 Zob. T. Mrówczyński, Personalizm Maritaina i współczesna myśl katolicka, Warszawa 1964, s. 92 . 
Kluczowa dystynkcja Maritaina, czyli rozróżnienie na osobę i jednostkę, została dokonana na kanwie klasycznej metafizyki tomistycznej, opisującej byt za pomocą takich kategorii, jak materia i forma. Jedna z fundamentalnych tez tomistycznych głosi, że cielesne stworzenia są złożone w samej swej istocie z możności i aktu; możność tę $\mathrm{i}$ akt w porządku istoty nazywamy materią i formą ${ }^{5}$. Materia jest substancjalnym elementem, stanowiącym rozciągłość (przestrzenność), na której dokonują się przemiany i utrzymują się przypadłości. Natomiast forma to element substancjalny, który stanowi o jedności i stałości bytów ${ }^{6}$. W człowieku materią jest ciało, zaś formą dusza. Tomistyczne rozwiązanie „podkreśla, że dusza i ciało - jako forma i materia - to dwie substancje niekompletne, które wspólnie dają początek jednej substancji kompletnej, czyli człowiekowi, który jest w swej istocie duszą i ciałem zarazem, bowiem dusza i ciało tworzą jedną całość"

Dla filozoficznego podbudowania swojej dystynkcji między osobą a jednostką Maritain odwoływał się wprost do kolejnego tomistycznego twierdzenia, wypływającego z uprzedniego określenia kategorii materii i formy; mianowicie do zasady, iż oznaczona co do swej ilości materia stanowi pierwiastek ujednostkowienia, to jest zasadę liczebnej różnicy pomiędzy jednym osobnikiem a drugim w obrębie tego samego gatunku. W każdym człowieku istnieje całkowita natura ludzka, ale gatunek pozostaje jeden, dzięki temu, że forma jest przyjmowana w oznaczonej i wyróżnionej materii, czyli w tym konkretnym ciele, które jest przez tę formę, a więc duszę, ożywiane 8 .

W swoich rozważaniach na temat człowieka francuski neotomista oscylował wokół klasycznej definicji osoby, podanej przez Boecjusza; w Humanizmie integralnym Maritain definiuje osobę jako „wszechświat o naturze duchowej, obdarzony wolnością wyboru i stanowiący tym

5 Por. É. Hugon, Zasady filozofii: dwadzieścia cztery tezy tomistyczne, tłum. A. Żychliński, Warszawa 2015, s. 55.

6 Por. É. Hugon, Zasady filozofii, s. 57-59.

7 H. Majkrzak, Antropologia integralna w „Sumie teologicznej” św. Tomasza z Akwinu, Kraków 2006, s. 125.

8 Por. É. Hugon, Zasady filozofii, s. 69-72. 
samym całość niezależną wobec świata. Ani natura, ani państwo nie mają dostępu do tego wszechświata bez jego pozwolenia. I nawet Bóg, który jest i działa wewnątrz, działa w nim w sposób szczególny i z przedziwną delikatnością, która wskazuje, jak bardzo się z nim liczy: szanuje jego wolność, choć mieszka w jej sercu, pobudza ją, lecz nigdy nie zadaje

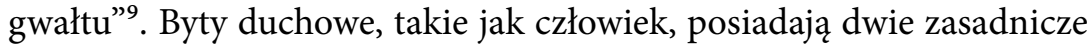
właściwości: rozumność i wolność. Rozumność wyraża się w intelektualnym poznaniu, zaś wolność w autoderminacji woli. Osoba jest osobą dzięki posiadaniu rozumności i wolności - te dwie cechy stanowią rdzeń osobowości, rozumianej jako istota osoby.

Osoba ma za przedmiot poznania obiektywną rzeczywistość. Ta rzeczywistość poza osobą rodzi w niej myśli bytujące ponad czasem. Człowiek nie poznaje ani poprzez samo doświadczenie, ani tylko drogą intelektualno-refleksyjną; tak jak jest on podmiotem wielu władz, tak też ludzkie poznanie jest wieloźródłowe. Maritain pisał nie tylko o doświadczeniu zmysłowym, lecz także artystycznym czy mistycznym.

W kwestii wolności ludzkiego wyboru filozof starał się znaleźć drogę pośrednią między indeterminizmem i klasycznym determinizmem. Uznał, że wolność nie jest zawieszeniem naturalnego porządku przyrody i jej praw; uważał, że jedynie zewnętrzny lub wewnętrzny przymus jest przekreśleniem wolności. Ludzką wolność, zdaniem francuskiego personalisty, należy określić jako relatywną (człowiek jest włączony w mechanizmy kosmosu), niemniej jednak realną (intelekt zawsze pozwala człowiekowi dostrzec wiele możliwych rozwiązań sytuacji ${ }^{10}$.

Tak zdefiniowaną osobę i jej osobowość Maritain zestawił z jednostką i jej indywidualnością. W książce Trzej reformatorzy, powołując się na św. Tomasza z Akwinu, podkreślił, że osoba jest tym, co najszlachetniejsze i najwznioślejsze w całej naturze; natomiast jednostka (indywiduum) to wymiar wspólny człowiekowi, zwierzęciu, roślinie, a nawet atomowi, istniejący dzięki własnym wymaganiom materii, która stanowi zasadę podziału. Jako jednostki, ludzie są zaledwie fragmentami materii,

\footnotetext{
9 J. Maritain, Humanizm integralny, tłum. J. Budzisz, Londyn 1960, s. 16.

10 Por. S. Kowalczyk, Wprowadzenie do filozofii J. Maritaina, Lublin 1992, s. 38-44.
} 
częścią wszechświata, podatną na siły i wpływy fizyczne, kosmiczne, dziedziczne itd. Jednakże jako osoby, ludzie przekraczają te wszystkie wpływy i stanowią transcendentną rzeczywistość ${ }^{11}$.

Już w tym miejscu narzuca się myśl o stanowiskach krytycznych wobec filozofii francuskiego neotomisty. Otóż krytycy Maritainowskiego rozróżnienia na osobę i indywiduum sygnalizują, „iż francuski autor nie odróżnił w sposób jednoznaczny zasady jednostkowienia i kategorii indywiduum. W interpretacji tomizmu zasadą jednostkowienia, czyli tym, co dzieli gatunek na jednostki, jest materia. Jednak czym innym jest to, co konstytuuje człowieka jako indywidualną całość. Nie jest to wyłącznie materia, lecz także elementy psychiczno-duchowe. Indywidualny wymiar ma zarówno ciało, jak i sfera duchowa człowieka. Zresztą św. Tomasz z Akwinu zarówno materię, jak i formę substancjalną uznał za zasadę jednostkowienia" ${ }^{\prime 2}$. Dobitnie ilustruje to komentator św. Tomasza z Akwinu - Édouard Hugon ${ }^{13}$, który uzupełnia tomistyczną tezę o materii jako pierwiastku ujednostkowienia konstatacją, iż „materia ujednostkawia się przez to, że odnosi się do pewnej ilości, która z istoty swej różna jest od innej ilości; forma zaś czerpie swe ujednostkowienie z tego, że jest przyjęta w oznaczonej i wyróżnionej materii; całe wreszcie złożone jestestwo otrzymuje swe ujednostkowienie od formy ujednostkowionej w wyłożony sposób"14 . W pismach Maritaina to uszczegółowienie zdaje się nieobecne. Fakt ten jawi się jako mankament stanowiska francuskiego neotomisty.

Osoba ludzka, choć stanowi bogaty i różnorodny mikrokosmos, nie jest zamkniętą monadą, lecz jestestwem otwartym na społeczność. Maritain podkreślił dwojakie powody podjęcia życia społecznego przez

11 Zob. J. Maritain, Trzej reformatorzy: Luter, Kartezjusz, Rousseau, tłum. K. Michalski, WarszawaZąbki 2005, s. 52.

12 S. Kowalczyk, Wprowadzenie do filozofii J. Maritaina, s. 61.

13 Édouard Hugon (1867-1929) - francuski dominikanin, filozof i teolog; wykładowca na Angelicum w Rzymie; jego prace, mające wysokie walory formalno-dydaktyczne, przyczyniły się do popularyzacji neotomizmu w pierwszej połowie XX wieku. Por. Encyklopedia katolicka, t. 6, red. zbiorowa, Lublin 1993, k. 1287.

14 É. Hugon, Zasady filozofii, s. 71-72. 
ludzi. Pierwszym z nich pozostaje potrzeba międzyosobowej interakcji, skorelowana $\mathrm{z}$ naturalnym pragnieniem osoby do dzielenia się $\mathrm{z}$ innymi posiadanymi wartościami czy to wyższymi, czy niższymi. Innym źródłem życia społecznego są rozmaite braki, jakich doświadcza człowiek w dziedzinie życia materialnego i biologicznego ${ }^{15}$. W celu ustalenia zależności między osobą a społecznością francuski myśliciel odwołuje się do dokonanego podziału na jednostkę i osobę.

Maritain wyjaśnia, iż człowiek jako jednostka jest podporząakowany dobru społeczności, której częścią pozostaje, w sensie partycypowania w dobrach niezbędnych mu do życia, a należących do społeczeństwa jako ogółu. To dobro wspólne jest, według niego, „bardziej boskie". Natomiast każdy człowiek jako osoba stoi ponad społecznością i jest podporządkowany bezpośrednio jedynie Bogu, będącemu celem ostatecznym i najwyższym dobrem osoby. W tym kontekście człowiek stanowi niezależną całość, a nie jedynie część wspólnoty. Człowiek rozpatrywany w aspekcie jednostkowości istnieje dla społeczności i w razie potrzeby powinien on poświęcić dla niej swoje życie; z kolei człowiek rozpatrywany w aspekcie osobowości dzierży palmę pierwszeństwa nad społecznością, która nie ma prawa do wykorzystywania go i narzucania mu niesprawiedliwości ${ }^{16}$.

Dla dopełnienia prezentacji Maritainowskiej myśli o człowieku należy zwrócić uwagę na fakt, że autor Humanizmu integralnego postrzegał osobę jako byt dynamiczny - osobowość człowieka „wzrasta w miarę, jak dusza, wznosząc się ponad świat zmysłowy, wiąże się coraz ściślej przez rozum i wolę z tym, co stanowi życie ducha. Człowiek, dzięki swym naczelnym władzom rozumu i woli, poprzez poznanie i miłość może osiągnąć pełnię swojej osobowości. Dzięki niej może wchodzić w kontakt $\mathrm{z}$ całym światem, niczego nie tracąc"17. To wspinanie się przez człowieka na szczyty osobowości (a zarazem doskonałości)

15 Por. S. Kowalczyk, Wprowadzenie do filozofii J. Maritaina, s. 60.

16 Zob. J. Maritain, Trzej reformatorzy, s. 53-55.

17 J. Grzybowski, Jacques Maritain i nowa cywilizacja chrześcijańska, Warszawa 2007, s. 198-199. 
sprawia, że zwiększa się ludzka godność ${ }^{18}$, która jest fundamentem licznych praw człowieka.

Najbardziej adekwatnym kontrargumentem wobec Maritainowskiego rozróżnienia na osobę i jednostkę zdaje się być spostrzeżenie uczynione przez M.F. Niemeyer, która „zarzuca Maritainowi przede wszystkim używanie logicznych pojęć jednostki ludzkiej i osoby w sensie pojęć metafizycznych. Jej zdaniem Maritainowskie odróżnienie pojęcia jednostki ludzkiej od pojęcia osoby nie opiera się na realnej różnicy przedmiotów tych pojęć i dlatego (...) nie może być np. podstawą rozważań na temat prymatu osoby nad społeczeństwem"19. Faktycznie, gdy francuski neotomista opisuje rzeczywistość osoby i jednostki, sprawia wrażenie (być może jest to efekt wspomnianej nieścisłości w wypowiadaniu się), jakby referował dwa odrębne jestestwa, w jakiś sposób nakładające się na siebie, podczas gdy są to przecież jedynie dwie odmienne perspektywy, w świetle których zgłębiana jest tajemnica ludzkiego bytu. Zdaniem J.A. Baisnéego całe to rozróżnienie jest sprzeniewierzeniem się św. Tomaszowi z Akwinu i przejawia znamiona wpływów platonizmu i kartezjanizmu ${ }^{20}$.

Pozostający w nurcie zachowawczego tomizmu, obawiającego się idealistycznych skażeń, Bernard Tissier de Mallerais uważa, że rozróżnienie dokonane przez Maritaina ,jest prawdziwe tylko w porządku nadprzyrodzonym, w którym osoba zostaje podniesiona ponad naturę przez łaskę uświęcającą; ale w porządku przyrodzonym jest błędne, bo tu osoba jest jednostką rozumnej natury, będącą częścią całości złożonej z natur rozumnych, a co za tym idzie, jest do niej przyporządkowana jako część do całości”21. W świetle tych słów można posądzić filozofa o pomieszanie porządku przyrodzonego z nadprzyrodzonym i odmienne

18 Por. L. Wciórka, Personalizm J. Maritaina a Vaticanum II, w: Jacques Maritain - prekursor soborowego humanizmu: myśl filozoficzno-teologiczna Jacques’a Maritaina, red. S. Kowalczyk, E. Balawajder, Lublin 1992, s. 49.

19 Za T. Mrówczyński, Personalizm Maritaina, s. 93-94.

20 Por. T. Mrówczyński, Personalizm Maritaina, s. 89.

21 B. Tissier de Mallerais, Portret filozoficzny Josepha Ratzingera, tłum. M. Beściak, Warszawa 2018, s. $160-161$. 
rozumienie synonimicznych terminów „osoby” i „jednostki”. Z opinią, że wyrazy te w filozofii św. Tomasza z Akwinu znaczą to samo, zgadzają się L. Lachance i L. Janssens ${ }^{22}$.

Identyczne stanowisko reprezentował najbardziej nieprzejednany krytyk Maritaina - Julio Meinvielle, który przekonywał, że Doktor Anielski „nie przeciwstawiał indywidualności - osobowości. Odróżnienie jednostki ludzkiej od osoby przez Maritaina (...) wynika (...) ze sprowadzenia wszelkiej indywidualności do indywidualności natur cielesnych. (...) Tymczasem dla Tomasza z Akwinu indywidualność nie jest $\mathrm{z}$ konieczności związana $\mathrm{z}$ materią, lecz odnosi się także do Boga i bytów duchowych, pokrywając się z ich osobowością"23. Maritain zdaje się uznawać tylko jedną zasadę indywidualizacji - materię, tymczasem, jak dowodzi J. Turowski, jest to uproszczenie wykoślawiające tomizm, albowiem materia jest racją ujednostkowienia, lecz nie wyłączną ${ }^{24}$.

Tomistyczni krytycy myśliciela, podkreślając, że państwo jest w rzeczywistości wyższe od osoby, która po prostu jest jednostką ${ }^{25}$, dodają, iż - paradoksalnie - Maritainowskie rozróżnienie na osobę i jednostkę nie chroni człowieka przed totalitaryzmem, lecz może zostać wykorzystane przez państwo totalitarne; skoro jednostka jest podporządkowana społeczeństwu, a życie doczesne musi być poświęcone dobru wspólnemu, to rzeczą całkowicie naturalną jest możliwość targnięcia się przez społeczeństwo na integralność ciała jednostki, np. poprzez sterylizację $^{26}$. Ten zarzut wydaje się najmniej trafny, ponieważ jawi się jako wzięcie tylko części prawdy za całość. Właśnie po to, ażeby uniknąć sytuacji opresyjnych ze strony państwa, Maritain mówił o człowieku także jako o osobie. Jednocześnie tym bardziej nie widać, jak tomizm bardziej klasyczny od Maritainowskiego miałby sobie poradzić z tego typu zakusami państwa.

${ }_{22}$ Por. T. Mrówczyński, Personalizm Maritaina, s. 94.
Za T. Mrówczyński, Personalizm Maritaina, s. 93.
24 Por. T. Mrówczyński, Personalizm Maritaina, s. 95.
25 Por. T. Mrówczyński, Personalizm Maritaina, s. 116.
26 Por. T. Mrówczyński, Personalizm Maritaina, s. 126. 


\section{Historyzm i progresywizm}

Kolejną grupę zarzutów wobec filozofii Maritaina stanowią te, które oscylują wokół takich zagadnień, jak historyzm i progresywizm. Poprzez pierwsze pojęcie rozumie się, najogólniej rzecz ujmując, przekonanie, że prawda w jakiejś mierze zależy od historii i podmiotu ją badającego ${ }^{27}$; zaś drugie wskazuje na stanowisko, że kultura ludzka stale się rozwija i kolejna epoka jest wyższa od poprzedniej ${ }^{28}$.

Kojarzące się z tymi kierunkami poglądy Maritaina można streścić w kilku punktach:

1. Chrześcijaństwo musi przyswoić sobie doświadczenia historii nowożytnej - należy ustanowić nową cywilizację chrześcijańską.

2. Absolutne i niezmienne zasady stosuje się analogicznie w zależności od klimatu historycznego danej epoki.

3. Istnieje immanentny kierunek historii - ludzkość dąży do coraz to większej świadomości i wolności.

4. Ludzkość osiągnęła dojrzałość - większą świadomość swojej własnej godności.

Zanim zostanie przedstawiona krytyka Maritainowskiego „ukąszenia" przez historyzm i progresywizm, stosowne będzie zaprezentowanie, przynajmniej w zarysie, kluczowych pojęć obecnych w tej problematyce, czyli „nowej cywilizacji chrześcijańskiej” oraz „analogii”.

Nowa cywilizacja chrześcijańska ma pozostać świecka, w przeciwieństwie do średniowiecznej - sakralnej, ze względu na świecki klimat naszej epoki historycznej. Ponadczasowe zasady relacji między państwem i Kościołem mają zostać zachowane, lecz w sposób analogiczny. Tymi zasadami są: po pierwsze, swoboda Kościoła w nauczaniu, modlitwie i kulcie ${ }^{29}$; po drugie, nadrzędność Kościoła, a więc ducha, nad ciałem politycznym lub państwem ${ }^{30}$; po trzecie, konieczność współpracy między

27 Zob. B. Tissier de Mallerais, Portret filozoficzny Josepha Ratzingera, s. 30-33.

28 Zob. D. von Hildebrand, Koń trojański w Mieście Boga, tłum. J. Wocial, Warszawa 2012, s. 149.

29 Por. J. Maritain, Człowiek i państwo, tłum. A. Grobler, Kraków 1993, s. 158.

30 Por. J. Maritain, Człowiek i państwo, s. 160. 
Kościołem a ciałem politycznym czy też państwem, wynikająca z samej natury rzeczy - człowiek jest zarazem członkiem państwa i Kościoła, brak współpracy między tymi dwoma wspólnotami byłby jakimiś przepołowieniem człowieka, co jest metafizyczną niedorzecznością ${ }^{31}$.

Jak to już zostało po części odnotowane, zdaniem Maritaina, zasady te są absolutne, niezmienne i ponadczasowe, lecz stosowane na sposób analogiczny ze względu na dany klimat historyczny, zwany inaczej konstelacją historyczną ${ }^{32}$. W różnych czasach realizowane są konkretne ideały historyczne, funkcjonujące w obrębie cywilizacji. Konkretny ideał historyczny można zdefiniować jako system społeczny, polityczny i prawny odzwierciedlający główne idee danej epoki historycznej. Choć wymaga on wysiłku, nie jest utopią niemożliwą do zrealizowania. Sakralna cywilizacja średniowiecza miała swój ideał - hierarchiczny, zakładający maksymalną jedność społeczną i służebność czynnika doczesnego wobec duchowego. Natomiast świecka i pluralistyczna cywilizacja współczesna ma swoje własne oryginalne wyznaczniki. Są nimi: pluralistyczna struktura społeczeństwa, autonomia doczesności w stosunku do czynnika duchowego, wolność osób, dążenie do ustanowienia wspólnoty braterskiej wszystkich ludzi oraz jedność substancji społecznej ${ }^{33}$.

Wyeksponowana wyżej analogia jest kolejnym fundamentalnym terminem filozofii tomistycznej, można się z nim spotkać, przede wszystkim, w kontekście języka religijnego i mówienia o Bogu. Jedna z podstawowych tez tomistycznych stwierdza, że bytu nie orzekamy o Bogu i o stworzeniach jednoznacznie ani też różnoznacznie, lecz analogicznie, na mocy analogii atrybucji i proporcjonalności ${ }^{34}$.

Édouard Hugon wyjaśnił tę tezę, odwołując się do przykładów. Piotr i Paweł są czymś jednoznacznym, o tyle, o ile są ujmowani pod kątem posiadanego przez nich człowieczeństwa; tak samo człowiek i pies są jednoznaczni pod tym względem, że należą do rodzaju zwierzęcego.

31 Por. J. Maritain, Człowiek i państwo, s. 160.

32 Zob. J. Maritain, Człowiek i państwo, s. 163-164.

33 Por. E. Niesyty, Miejsce i rola personalistycznej koncepcji społeczeństwa demokratycznego whumanizmie integralnym Jacques'a Maritaina, Poznań 2005, s. 153.

34 Por. É. Hugon, Zasady filozofii, s. 22. 
Różnoznaczność zachodzi wtedy, kiedy wyraz pozostaje wspólny, a wyrażona realność zupełnie odmienna. Tak jest $\mathrm{w}$ przypadku słowa „zamek", które raz oznacza budowlę, innym razem zatrzask u drzwi. Z analogią mamy do czynienia wówczas, gdy wyraz jest wspólny, a oznaczona realność nie jest ani całkiem ta sama, ani całkiem różna, lecz zawiera jakiś stosunek i podobieństwo istniejące między opisywanymi rzeczami. Człowiek może być „zdrowy”, pokarm może być „zdrowy” i cera może być „zdrowa”, lecz nie w tym samym sensie. Człowiek jest „zdrowy” jako podmiot cieszący się zdrowiem, pokarm jest „zdrowy”, ponieważ powoduje zdrowie, zaś cera jest „zdrowa” jako skutek zdrowia ${ }^{35}$. Różnica między analogią atrybucji a proporcjonalności jest następująca: wtedy, kiedy „realność oznaczona wspólnym wyrazem, orzeka się o jednej rzeczy przez wzgląd na inną, która daną realność we właściwym znaczeniu posiada (...), wówczas mamy analogię atrybucji, czyli przypisywania" ${ }^{36}$; natomiast, gdy „oznaczona realność znajduje się prawdziwie i wewnętrznie we wszystkich rzeczach objętych wspólną nazwą, choć nie całkiem w ten sam sposób" ${ }^{\text {"37 }}$, wtenczas mamy analogię proporcjonalności, czyli stosunkowości.

W przypadku trzech zasad relacji między Kościołem a państwem, stosowanych $\mathrm{w}$ różnych cywilizacjach, przy różnych konstelacjach historycznych, spotykamy się z analogią proporcjonalności.

Dzięki analogii zasady relacji między Kościołem a państwem w nowej cywilizacji chrześcijańskiej powinny przybrać nowe kształty. Maritain wskazał, że obecnie zasada nadrzędności Kościoła powinna się realizować w niczym nieskrępowanej nieodpartej sile wszechogarniającej inspiracji społeczeństwa politycznego przez Kościół, szczególnie pożądanej w dziedzinie edukacji ${ }^{38}$. Zasada współpracy Kościoła z państwem powinna przyjąć taką postać, ażeby państwo w bezwzględny sposób wypełniało swój polityczny obowiązek stwarzania w społeczeństwie

35 Zob. É. Hugon, Zasady filozofii, s. 22-23.

36 É. Hugon, Zasady filozofii, s. 23.

37 É. Hugon, Zasady filozofii, s. 23.

38 Zob. J. Maritain, Człowiek i państwo, s. 169-170. 
warunków gwarantujących osobie ludzkiej możliwość: realizacji jej celów, korzystania z praw, wykonywania obowiązków i pełnego rozkwitu ${ }^{39}$. Dla francuskiego neotomisty rzetelne sprawowanie przez państwo jego bezpośredniej władzy nad życiem doczesnym obywateli jest zasadniczo sprawowaniem jego pośredniej władzy i obowiązku popierania oraz wspomagania Kościoła, albowiem problem duchowy naszych czasów ma swoje centrum, w gruncie rzeczy, w porządku doczesnym. Nowoczesne „państwo dobrobytu”, po prostu zmierzające do dobrostanu ludzi, oddaje Kościołowi lepsze usługi niż kiedykolwiek oddali chrześcijańscy cesarze $^{40}$.

Postulat „państwa dobrobytu” jest pomysłem na realizację ogólnej formy współpracy Kościoła z państwem, natomiast co do szczególnych form współdziałania tychże, na pierwszy plan wysuwa się urzeczywistnianie ostatniej zasady relacji między Kościołem i państwem - zasady wolności Kościoła, która jest realną, choć negatywną współpracą ${ }^{41}$. Państwo winno dać Kościołowi swobodę w działaniu, zaś o sukcesy w misji zbawczej Kościoła zatroszczy się Duch Święty, działający poprzez wybranych ludzi.

Cała ta historiozoficzna narracja, posługująca się pojęciem „konkretnego ideału historycznego", zdaje się być usprawiedliwiona jedynie wówczas, gdy założy się, że historia ma swój sens i kierunek nie tylko w perspektywie eschatologicznej, ale także w obrębie samego doczesnego porządku.

Salleron dopatrzył się w koncepcjach Maritaina determinizmu historycznego. Jego zdaniem Maritain ma prawo do periodyzacji dziejów na „wieki cywilizacji” bądź „czasy historyczne”, jednak bezzasadnie uważa on, że jest w stanie określić wszystkie komponenty teraźniejszości, jakie determinują przyszłość ${ }^{42}$. Salleron wskazuje na zależność filozofii Maritaina od poglądów Marksa. Francuski neotomista, choć

\footnotetext{
39 Zob. J. Maritain, Człowiek i państwo, s. 178-179.

40 Zob. J. Maritain, Człowiek i państwo, s. 179.

41 Zob. J. Maritain, Człowiek i państwo, s. 184.

42 Por. M. Davies, Sobór papieża Jana, s. 341.
} 
wierzy w wolność i ma inny cel niż marksiści, dzieli z nimi przekonanie co do faktu, że historia współczesna obierze konkretny kierunek i nastąpi zwycięstwo socjalistycznego humanizmu, który Maritain pragnie „ochrzcić” ${ }^{43}$. Salleron pozostaje pesymistyczny w kwestii ludzkich zdolności przewidywania przyszłości. Nawet, gdybyśmy poznali cały układ sił warunkujący teraźniejszość, i tak przyszłość przyniesie nam niespodzianki. Maritain pragnie schrystianizować to, co jawi mu się jako nieuchronne. Gdyby w jego ojczyźnie pojawiła się nowa św. Joanna d’Arc, wzywająca np. do wymiany ciosów, w imię Boże, z marksizmem, Maritain odesłałby ją do rodziców, twierdząc, że takie krwiożercze upodobanie do walki nie przystoi w aktualnej fazie historii. Natomiast Joanna mogłaby mu odpowiedzieć, że Bóg ma księgę, z której żaden pisarz sądowy nigdy nie korzystał, bez względu na to, jak biegłym mógł być w swojej sztuce ${ }^{44}$. Do tego stanowiska hipotetycznej Joanny przychyla się Salleron, który sprawia wrażenie człowieka bardziej pesymistycznego aniżeli twórca humanizmu integralnego ${ }^{45}$.

Krytyczna refleksja Sallerona nad koncepcją dziejów Maritaina nie wydaje się pogłębiona. W opozycji do niej należy zaakcentować przynajmniej to, że konkretny ideał historyczny w jego filozofii nie musi się ziścić. Gdy historyczne przeszkody przybierają skrajną postać, ideał może zostać niezrealizowany ${ }^{46}$.

Ideowo bliski Maritainowi (poprzez krytykę teilhardyzmu) Dietrich von Hildebrand podchodził $\mathrm{z}$ rezerwą do koncepcji osiągnięcia przez ludzkość dojrzałości. Autor Konia trojańskiego w Mieście Boga wskazał, że symptomatycznym „objawem niedojrzałości jest sytuacja, kiedy ktoś czuje się bardziej dojrzały i niezależny od ludzi żyjących wcześniej,

43 Por. M. Davies, Sobór papieża Jana, s. 343.

44 Zob. M. Davies, Sobór papieża Jana, s. 347-350.

45 Niektórzy krytycy jako największy błąd Jacques’a Maritaina postrzegają jego optymizm, zwany przez nich nawet hurraoptymizmem. Rafael Gambra nazwał jego filozoficzne podejście wprost idealistycznym i przesadnie optymistycznym, zupełnie sprzecznym z katolicką antropologią, podkreślającą zranienie ludzkiej natury grzechem pierworodnym. Por. J. Bartyzel, Śmiertelny bóg Demos: pięć wykładów o demokracji i jej krytykach, Warszawa 2009, s. 161.

${ }^{46}$ Por. E. Niesyty, Jacques'a Maritaina teoria przełomu psychokulturowego na tle nowożytnych teorii myślenia społecznego: chrześcijanin wobec kultury i historii, Poznań 1997, s. 124. 
kiedy zapomina o własnym długu wdzięczności wobec czasów przeszłych, i kiedy - z młodzieńczą pewnością siebie - odrzuca wszelką pomoc" ${ }^{17}$. Zdaniem niemieckiego fenomenologa taka sytuacja miała miejsce już kilka wieków temu i powiela się w XX stuleciu z większą intensywnością ${ }^{48}$.

O tym, że ludzkość jest niedojrzała, świadczą takie sytuacje, jak: „detronizacja prawdy przez relatywizm historyczny, fetyszyzacja nauki, niszczenie naszego życia w efekcie laboratoryjnego podejścia don'" ${ }^{\prime \prime 9}$, większy niż wcześniej odsetek bezwartościowych książek i artykułów zniewalających umysły intelektualistów ${ }^{50}$, wreszcie - nasilające się zjawisko polegania na sloganach zastępujących prawdę i mądrość ${ }^{51}$. Arcybiskup Marcel Lefebvre, krytykując Vaticanum II, odnotował fakt, że dla liberalnych katolików historia ma swój sens/kierunek, który jest immanentny $i$ jest on wolnością, wykraczającą poza wszelkie granice ${ }^{52}$. Jednakże Objawienie nie poucza o żadnym immanentnym kierunku historii. Dzieje mają cel transcendentny, a nie immanentny. Tym celem jest odrodzenie wszystkiego w Chrystusie ${ }^{53}$. Nie posiadamy żadnej instancji, która mogłaby orzec, że ludzkość już osiągnęła dojrzałość. Maritainowskie założenie o dorosłości rodzaju ludzkiego wydaje się pozostawać czymś arbitralnym.

Ten sam hierarcha zauważył, że „Maritain był oślepiony cywilizacją otwarcie pluralistycznego typu jak w Stanach Zjednoczonych, w środku której Kościół katolicki, delektujący się systemem zwykłej wolności, doświadczył godnego uwagi znacznego wzrostu liczby członków i swych instytucji" ${ }^{34}$. Zarówno Maritain, jak i jego nauczyciel Henri Bergson ${ }^{55}$

47 D. von Hildebrand, Koń trojański, s. 193.

48 Zob. D. von Hildebrand, Koń trojański, s. 194.

49 D. von Hildebrand, Koń trojański, s. 193.

50 Por. D. von Hildebrand, Koń trojański, s. 194.

51 Por. D. von Hildebrand, Koń trojański, s. 196.

52 Zob. M. Lefebvre, Oni Jego zdetronizowali: od liberalizmu do apostazji: tragedia soborowa, Warszawa 2002, s. 135.

53 Zob. M. Lefebvre, Oni Jego zdetronizowali, s. 137.

54 M. Lefebvre, Oni Jego zdetronizowali, s. 130.

${ }_{55}$ Henri Bergson żywił uznanie dla ustroju demokratycznego. Szczególnie bliska była mu demokracja amerykańska. Jego zdaniem demokracja niesie ze sobą uszanowanie prawa i odporność 
byli zauroczeni amerykańską demokracją i jej strukturami. Przebywający przez dłuższy czas na emigracji Maritain wypowiadał się w przychylny sposób o modelu relacji między państwem a Kościołem w Stanach Zjednoczonych Ameryki Północnej, który zakłada rozdział tych rzeczywistości, lecz nie wrogośćc ${ }^{56}$.

\section{Amerykanizm}

Preferencje Maritaina wpisują się w nurt amerykanizmu, który jest amalgamatem takich idei, jak: wyższość amerykańskiego modelu życia społecznego i religijnego nad europejskim, konieczność przejęcia przez Kościół pewnych swobód obywatelskich występujących w Stanach Zjednoczonych Ameryki Północnej, wreszcie - wyższość aktywizmu nad życiem kontemplatywnym. Najprawdopodobniej Maritain nie zgodziłby się z tym ostatnim zdaniem, jednakże jego tezy korespondują z tymi postulatami amerykanizmu, jakie odnoszą się bardziej do życia publicznego aniżeli osobistego. Nowa cywilizacja chrześcijańska, która realizuje zasady relacji między Kościołem i państwem w nowy analogiczny sposób, zakłada istnienie „państwa dobrobytu” jako najlepszej gwarancji wzrostu Kościoła oraz przyjmuje za jeden ze swoich wyznaczników wolność osób (w tym wolność sumienia i religijną), zdecydowanie przypomina amerykański model cywilizacyjny, którego propagatorzy w obrębie katolicyzmu zostali nazwani amerykanistami.

Nurt ten rozwijał się w amerykańskim Kościele w XIX wieku i spotkał z potępieniem ze strony Stolicy Apostolskiej. Papież Leon XIII w 1895 roku w encyklice Longinqua oceani przestrzegał, że stosunki panujące

wobec przemocy w stosunkach międzynarodowych. Powinna ona wyznaczać drogi ludom i społeczeństwom, albowiem tylko ona odwołuje się do wzniosłych haseł braterstwa ludzi. Ideał ten mógł powstać jedynie $\mathrm{w}$ chrześcijańskim środowisku, dzięki ewangelicznym zasadom miłości. Bergson odwoływał się do dzieł demokratycznych pisarzy i wskazywał, że Kant zawdzięczał wiele pietyzmowi, natomiast Rousseau pozostawał pod wpływem zarówno protestantyzmu, jak i katolicyzmu. Amerykańska Deklaracja Niepodległości (1776) miała purytańskie podłoże i może stanowić wyznacznik dla innych deklaracji respektujących niezbywalne prawa człowieka. Por. B. Skarga, Czas i trwanie: studia o Bergsonie, Warszawa 1982, s. 229.

56 Zob. J. Maritain, Człowiek i państwo, s. 189-190. 
w Stanach Zjednoczonych między Kościołem a państwem nie mogą zostać uznane za coś doskonałego i ostatecznego, ponieważ religijna obojętność państwa zawsze okazuje się zgubna dla Kościoła. W liście apostolskim Testem benevolentiae ten sam papież pouczył, że amerykaniści błędnie przyjęli postępowy punkt widzenia, nakazujący Kościołowi dostosować swoje nauczanie do wymogów współczesności. Amerykanizm, choć zdemaskowany i napiętnowany, rozrósł się w XX wieku, kiedy to Europa została poniżona przez wielkie wojny, zaś USA stało się liderem światowej gospodarki ${ }^{57}$. Maritain, wpisując się mniej lub więcej w omawiany prąd intelektualny, również dodał mocy amerykańskim koncepcjom relacji między Kościołem a państwem, lecz tym samym naraził się na niezgodność z nauczaniem Leona XIII.

Na odstępstwo Maritaina od doktryn zawartych w papieskich dokumentach zwrócił uwagę głównie Meinvielle, który, porównując filozofa do Félicité Roberta de Lamennais ${ }^{58}$ i Marca Sangniera ${ }^{59}$, orzekł, że koncepcje Maritaina podpadają pod potępienia zawarte w takich XIX-wiecznych encyklikach, jak Mirari vos czy Quanta cura ${ }^{60}$. Ta ostatnia zawierała załącznik z szeregiem błędów nowożytnych, podsumowanych stwierdzeniem, że biskup Rzymu nie może pogodzić się z postępem i nowożytną cywilizacją. Jak już można było zauważyć, Maritain proponuje inne rozwiązanie, bardziej ugodowe wobec współczesności i jej ideowego klimatu. Zamiast przeciwstawiania sił chrześcijańskich i racjonalistycznych czy liberalnych, nakłania do współpracy opartej na ogólnoludzkich wartościach. Zainspirowany, jak się zdaje, Konstytucją Stanów Zjednoczonych Ameryki Północnej brał udział w tworzeniu powojennej Deklaracji Praw Człowieka przyjętej przez Organizację

57 Por. H. Hajducki, Amerykanizm, „Zawsze Wierni” 68 (2005) nr 1, s. 6-7.

58 Félicité Robert de Lamennais (1782-1854) - francuski pisarz i działacz religijno-społeczny; opowiadał się za rozdziałem Kościoła od państwa i emancypacją ludu; potępiony przez papieża Grzegorza XVI za sprawą encyklik Mirari vos i Singulari nos. Zob. Encyklopedia katolicka, t. 10, red. zbiorowa, Lublin 2004, k. 430-431.

59 Marc Sangnier (1873-1950) - francuski filozof i polityk; inicjator ruchu społecznego o nazwie Sillon; potępiony przez papieża św. Piusa X w liście apostolskim Notre Charge Apostolique. Zob. Encyklopedia katolicka, t. 17, red. E. Gigilewicz, Lublin 2012, k. 1042-1043.

60 Por. T. Mrówczyński, Personalizm Maritaina, s. 38. 
Narodów Zjednoczonych w 1948 roku. Badacze wskazują na jego wybitną rolę w zaakcentowaniu pierwszorzędnego znaczenia rozumu praktycznego w komponowaniu katalogu praw człowieka. Takie postawienie sprawy odwróciło uwagę od teoretycznych podstaw dokumentu i pozwoliło na konsensus pomiędzy przeciwstawnymi światopoglądami ${ }^{61}$.

\section{Zakończenie}

Wspomniany wcześniej Meinvielle streścił błędy Maritaina w trzech punktach, którymi jako wyznacznikami do dalszej refleksji, warto podsumować niniejszy artykuł. Są to, po pierwsze, uznanie nowoczesnych wolności; po drugie, liberalna koncepcja społeczeństwa i uznanie postępowości tegoż względem średniowiecznej struktury społecznej; po trzecie, ideał nowej cywilizacji chrześcijańskiej opartej na antychrześcijańskich zasadach $^{62}$. Te zarzuty są typowymi uwagami podnoszonymi przez środowiska integrystyczne wobec reprezentantów tzw. „katolicyzmu otwartego", którzy uważają Maritaina za prekursora ich ruchu.

Do tych uwag należy dodać jako filozoficznie najbardziej frapujący problem, mgliste rozróżnienie na osobę i jednostkę, które zdaje się rozdzierać człowieka i stawiać życie społeczne na rozdrożu między uznaniem osoby i jej wolności jako naczelnej wartości a dążeniem do dobra wspólnego, które jest właściwym funkcjonowaniem danej społeczności i w przeszłości zdecydowanie wiązało się nawet z przejawami ograniczania swobód obywatelskich, takich jak wolność sumienia czy religii.

Ciekawym przedsięwzięciem byłaby próba analizy projektu nowej cywilizacji chrześcijańskiej i jego ewentualnego powodzenia albo klęski. Takie praktyczne rozważania mogłyby rzucić nowe światło na twierdzenia zawarte w myśli Maritaina.

61 Por. F. Mazurek, Godność osoby ludzkiej podstawa praw człowieka, Lublin 2001, s. 130.

62 Por. T. Mrówczyński, Personalizm Maritaina, s. 39. 


\section{Bibliografia}

Bartyzel J., Śmiertelny bóg Demos: pięć wykładów o demokracji i jej krytykach, Warszawa 2009.

Davies M., Sobór papieża Jana: rewolucja liturgiczna, tłum. A. Zdziech, Komorów 2011. Encyklopedia katolicka, t. 6, red. zbiorowa, Lublin 1993.

Encyklopedia katolicka, t. 10, red. zbiorowa, Lublin 2004.

Encyklopedia katolicka, t. 17, red. E. Gigilewicz, Lublin 2012.

Grzybowski J. Jacques Maritain i nowa cywilizacja chrześcijańska, Warszawa 2007.

Hajducki H., Amerykanizm, „Zawsze Wierni” 68 (2005) nr 1, s. 5-15.

Hildebrand D. von, Koń trojański w Mieście Boga, tłum. J. Wocial, Warszawa 2012.

Hugon É., Zasady filozofii: dwadzieścia cztery tezy tomistyczne, tłum. A. Żychliński, Warszawa 2015.

Kowalczyk S., Wprowadzenie do filozofii J. Maritaina, Lublin 1992.

Lefebvre M., Oni Jego zdetronizowali: od liberalizmu do apostazji: tragedia soborowa, Warszawa 2002.

Majkrzak H., Antropologia integralna w „Sumie teologicznej” św. Tomasza z Akwinu, Kraków 2006.

Maritain J., Człowiek i państwo, tłum. A. Grobler, Kraków 1993.

Maritain J., Humanizm integralny, tłum. J. Budzisz, Londyn 1960.

Maritain J., Trzej reformatorzy: Luter, Kartezjusz, Rousseau, tłum. K. Michalski, Warszawa-Ząbki 2005.

Mazurek F.J., Godność osoby ludzkiej podstawą praw człowieka, Lublin 2001.

Mrówczyński T., Personalizm Maritaina i współczesna myśl katolicka, Warszawa 1964.

Niesyty E., Jacques'a Maritaina teoria przełomu psychokulturowego na tle nowożytnych teorii myślenia społecznego: chrześcijanin wobec kultury i historii, Poznań 1997.

Niesyty E., Miejsce i rola personalistycznej koncepcji społeczeństwa demokratycznego whumanizmie integralnym Jacques'a Maritaina, Poznań 2005.

Skarga B., Czas i trwanie: studia o Bergsonie, Warszawa 1982.

Tissier de Mallerais B., Portret filozoficzny Josepha Ratzingera, tłum. M. Beściak, Warszawa 2018.

Wciórka L., Personalizm J. Maritaina a Vaticanum II, w: Jacques Maritain - prekursor soborowego humanizmu: myśl filozoficzno-teologiczna Jacques'a Maritaina, red. S. Kowalczyk, E. Balawajder, Lublin 1992. 


\section{Abstrakt}

\section{Sporne zagadnienia antropologiczne i historiozoficzne w rozważaniach Jacques'a Maritaina}

Celem artykułu jest omówienie problematyki związanej z filozofią francuskiego neotomisty Jacques’a Maritaina. Szczególny akcent położony jest na stanowiska krytyczne wobec rozwiązań proponowanych przez Maritaina, ponieważ ten aspekt jest mało rozpowszechniony w polskiej refleksji personalistycznej. Podstawowe pytanie, jakie przyświeca podjętym tu rozważaniom, odnosi się do jakości i zasadności takich Maritainowskich teorii, jak nowa cywilizacja chrześcijańska oraz rozróżnienie na osobę i jednostkę. Całość rozważań osadzona jest na gruncie filozofii klasycznej, ponieważ Maritain starał się być kontynuatorem tej myśli.

\section{Słowa kluczowe}

Jacques Maritain, humanizm integralny, personalizm, nowa cywilizacja chrześcijańska, integryzm

\section{Abstract}

\section{Contentious Anthropological and Historiosophical Issues in Jacques Maritain's Deliberations}

The aim of the article is to discuss the issues related to the philosophy of the French neothomist Jacques Maritain. Special emphasis is placed on positions critical of the solutions proposed by Maritain, because this aspect is not very common in polish personalistic reflection. The fundamental question which determined considerations in article is the quality and validity of such Maritainian theories as the new christian civilization and the person-to-individual distinction. All considerations are based on classical philosophy, because Maritain tried to be a continuator of this trend.

\section{Keywords}

Jacques Maritain, integral humanism, personalism, new christian civilization, integrism 